\title{
Paleodiet in the Iberian Peninsula: exploring the connections between diet, culture, disease and environment using isotopic and osteoarchaeological evidence
}

\author{
Olalla López-Costas ${ }^{1,2,3} \cdot$ Michelle Alexander ${ }^{4}$ \\ Published online: 26 July 2019 \\ (C) Springer-Verlag GmbH Germany, part of Springer Nature 2019
}

\section{Iberian Peninsula and its great potential for understanding the human past}

It has been said that Iberia is more of a subcontinent than a Peninsula. Gross differences in environment and culture dominate the Iberia Peninsula today, which are directly connected to a rich panorama in the past. This southwestern corner of Europe combines intricate cultural backgrounds, wide climatic transitions and biogeographical differences in resources. The underlying geology and climate produce a wide variety of soil types resulting in different preservation conditions and diagenesis of archaeological material and human remains (i.e. highly acidic to highly alkaline soils). Important climatic differences exist between north and south, west and east, between inland areas and the Atlantic and Mediterranean coasts and the islands. Nothing is static, abrupt changes in climate through the Holocene also had an impact on human societies, to which we see a diversity of responses.

Olalla López-Costas olalla.lopez@usc.es

Michelle Alexander michelle.alexander@york.ac.uk

1 EcoPast research group (GI-1553), Facultade de Bioloxía, Universidade de Santiago de Compostela, 15782 Santiago de Compostela, Spain

2 Archaeological Research Laboratory, Wallenberglaboratoriet, Stockholm University, SE-10691 Stockholm, Sweden

3 Laboratorio de Antropología Física, Departamento de Medicina Legal, Toxicología y Antropología Física, Facultad de Medicina, Universidad de Granada, 18012 Granada, Spain

4 BioArCh, Department of Archaeology, University of York, Environment Building 2nd Floor, Wentworth Way, Heslington, York YO10 5DD, UK
The Iberian Peninsula does not, of course, exist in isolation. From prehistory to the present day, connections with societies in other geographic areas, on a European, and later, global scale, led to the human populations resident in the Peninsula playing a highly significant role in key narratives in human history. During prehistory, the peninsula is particularly notable for playing host to a great diversity in funerary rites, and many questions remain unresolved regarding major changes to society such as the Mesolithic-Neolithic transition, the emergence of new societies in the Chalcolithic and Bronze Age and the dynamics of wider connections with other European regions in the Iron Age. Hispania, as it was called during the Roman period, was a key area for raw materials and agriculture and played an important role during both the formation and fall of the Empire. The peninsula was later significant for harbouring a multifaith society during Medieval period, where the intersection of the major religions of Islam, Judaism and Christianity led to a uniquely blended culture. The presence of Islamic rule over much of the peninsula for nearly 800 years (711$1492 \mathrm{AD}$ ) was responsible for the introduction and spread of new technology and agricultural practices and products, the socalled green revolution (Watson 1974, but see Decker 2009). Christian kingdoms, however, persisted in the north and slowly expanded south throughout the later Medieval period (the socalled Reconquista) and were particularly notable for the significant pilgrimage centre of Santiago de Compostela and for the presence of Christian military orders (Pluskowski et al. 2011). After 1492, The now Christian Kingdoms of Spain and Portugal were central protagonists in the contact between the Old and New Worlds, responsible for the expansion of Roman Catholicism and leading the European connections with Americas, and areas of Africa and Asia. The Columbian and Southwestern Asia exchange are good examples of this. This extremely brief summary of the highlights of the multi-faceted history of the Peninsula and its deep connections with the rest of 
the world exemplifies what makes this region exceptional for the archaeological study of human lifestyles.

Archaeology has long been providing a window on this complex sociocultural history, and palaeodietary studies are particularly well placed to provide key insights into everyday life. Few things define how and why we live as we do better than diet. The dietary intake of a population results from a combination between the availability of resources, mainly driven by environment, and food preferences, with a strong connection to identity and culture, and with variation by, for example, social status, age and gender (Twiss 2012). The application of carbon $\left(\delta^{13} \mathrm{C}\right)$ and nitrogen $\left(\delta^{15} \mathrm{~N}\right)$ isotopes to human and animal remains from the Peninsula benefits from the isotopic variability inherent in the foods consumed in the past, playing to the strengths (and sometimes weaknesses) of the technique. Both $\mathrm{C}_{3}, \mathrm{C}_{4}$ (millets, sorghum, sugar cane, maize) and marine foods from the Atlantic and Mediterranean seaboards were consumed in a range of differing environments, which makes for a complex but fascinating scenario for palaeodietary interpretation. The Iberian Peninsula and surrounding islands are altogether an ideal in vivo laboratory to explore ancient lifestyle by linking diet with environment, health and culture. There was, however, no single 'Iberian paleodiet', multiple small narratives concerning different populations and periods are needed to better address the relationship between humans and food. The special issue "Iberian Paleodiet" aimed to achieve exactly this by bringing together the most recent projects to reconstruct past diets through the direct analyses of the human remains. We feel that this was a great success, with a total of 19 research articles revealing the stories of more than 900 new Iberian individuals.

\section{Chronological and geographical scope of the contributions}

The manuscripts included in the special issue "Iberian Paleodiet" generate a large body of new data and in one case provide a timely review of published data concerning paleodietary reconstruction using human (and animal) remains spanning a period over the last 10,000 years, almost the entire Holocene (Table 1). There is nearly a continuous chronological span; however, some periods are more represented than others (e.g. the Chalcolithic and Late medieval periods) while others have not been included (e.g. the Iron Age) or only feature briefly (e.g. the Roman period). Taking in the current published literature focusing on paleodietary reconstruction using isotope and dental microwear analyses in the Iberian Peninsula, a similar pattern can be found, with Prehistory being an early focus of such studies (see a good review in Cubas et al. 2018) with a new emergence of Late Medieval research (good reviews can be found in Curto et al.
2018; Inskip et al. 2018). One of the underlying factors in this distribution of research is likely to be mortuary practices where societies of the Iron Age and early Roman period tended to cremate their dead. High temperatures destroy bone collagen and alters dental enamel, complicating the isotopic methods of dietary reconstruction (Schurr and Hayes 2008). See García-Collado et al. (2018) for a targeted discussion of the issues surrounding the preservation and analysis of early medieval burials in particular in Spain.

Figure 1 depicts the locations of the sites included in the publications in this volume. Coastal, inland areas and surrounding islands are well-represented, but the majority them are focused on the modern geopolitical area of Spain (16/19) with two in Portugal (Curto et al. 2018; Toso et al. 2019) and one considering sites across the Iberian Peninsula as a whole (Cubas et al. 2018, not depicted in Fig. 1). Spain represents the largest geographical area in the Peninsula, which might account for some of the disparity. There has, however, been a general increase in the intensity of research in archaeological science by both Spanish and Portuguese research groups more recently.

\section{Comprehending consumption during prehistory}

A total of eight papers included in the special issue "Iberian Paleodiet" are focused on Prehistory, from c. $8000 \mathrm{BC}$ to c. $800 \mathrm{BC}$ (see Table 1). They relate diet to other characteristics of the population (e.g. demography), burial type (e.g. funerary ritual, body position), chronology and environment to address differences in diets by social status, religious identity, age and/or gender. When comparison among sites is carried out, variations associated with chronology and geography were observed. Cubas et al. (2018) explore the transition from the Mesolithic to Late Neolithic, revisiting data from an impressive 763 human individuals and 283 animal remains from across the Iberian Peninsula. They found significant differences in human diets over time and between the Atlantic and Mediterranean coasts (Cubas et al. 2018). The mosaic of environments present in the Iberian Peninsula in particular was exploited by Mesolithic individuals, reflected in a diversification of their diet (Cubas et al. 2018). The dietary information provided by this study is an excellent example of the power of integrating a large, comprehensive dataset. They report a relatively homogeneous diet based on $\mathrm{C}_{3}$ plants with some contribution of animal protein during the Neolithic, a dietary profile that has also been detected for early farming communities at north-central, north-eastern and south-central Spain (Díaz-Zorita Bonilla et al. 2019; Jones et al. 2019; Sarasketa-Gartzia et al. 2018; Villalba-Mouco et al. 2018). 







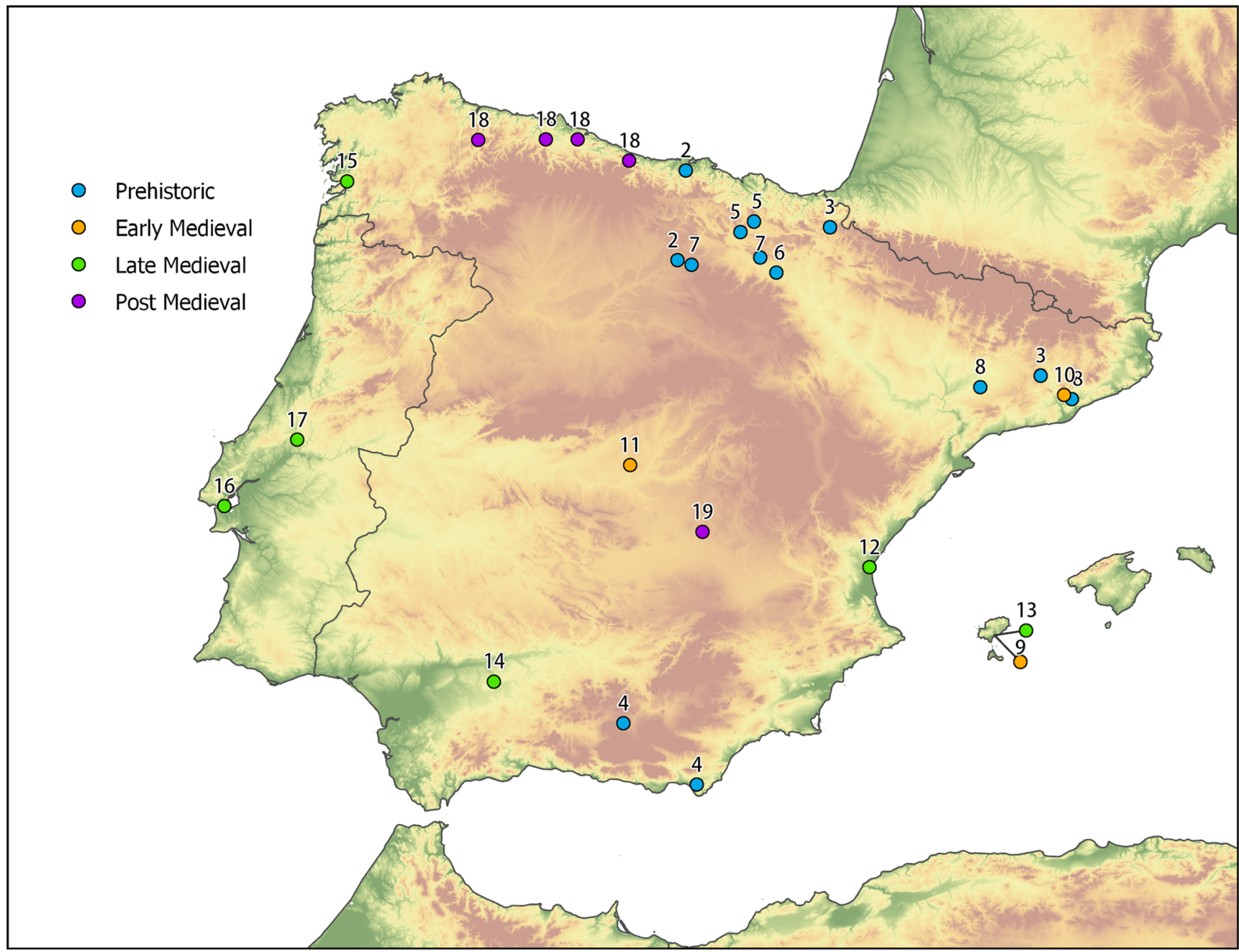

0 125

$\mathrm{km}$

Fig. 1 Map depicting simplified locations of the sites included in the volume, numbered as per Table 1 . In certain cases where multiple sites are in close proximity, one circle is depicted, i.e. San Salvador de Valdediós and San Julián de Viñón and San Miguel de Lillo, San Pedro de Nora, Catedral de San Salvador, Iglesia hospital de San Juan Bautista y San Isidoro and Castiellu de Llagú in Asturias (MacKinnon et al. 2019)

During the Late Neolithic and Chalcolithic, small intrasite variations were detected within populations from Barcelona and Navarra (Villalba-Mouco et al. 2018), Cantabria and Burgos (Jones et al. 2019), Araba (Villalba-Mouco et al. 2018) and Granada and Almería (Díaz-Zorita Bonilla et al. 2019). However, this intrapopulation homogeneity was not universal for all communities; differences in animal protein intake related to age (García-González et al. 2018 in this work sex could not be tested due to skeletal preservation) and both sex and age (Fernández-Crespo et al. 2018) were discovered at Chalcolithic sites in the Northcentral region, i.e. Rioja, Araba and Burgos. Subadults and females had apparently

and Arroyal I, El Hornazo, Fuente Celada and Ferrocarril-La Dehesa (Jones et al. 2019). For simplicity, all Asturias sites are shown as postmedieval, although some sites are medieval. Paper no. 1 (Cubas et al. 2018) is not included as this was a review including a large number of sites. Map created with data from Natural Earth and the Shuttle Radar Topography Mission (SRTM) with Helen Goodchild (York University)

less animal protein intake than males. Similar sex, and possibly gender, pattering was observed at the Bronze Age site of Can Roqueta (Barcelona) (Grandald'Anglade et al. 2019). In the Bronze Age, however, communities from north and south-eastern Iberia increased their intra-population variation (Díaz-Zorita Bonilla et al. 2019; Grandal-d'Anglade et al. 2019), possibly related with an increment in social complexity.

The lack of marine resources as a dietary staple seems consistent for all studied prehistoric groups. We agree with authors (Díaz-Zorita Bonilla et al. 2019) that this is a surprising fact, especially when analysing sites relatively close to the sea such as El Barranquete (Almeria, $\sim 7 \mathrm{~km}$ ). Papers also 
approached other aspects including weaning (GarcíaGonzález et al. 2018; Grandal-d'Anglade et al. 2019). Finally, the contributions studied a range of funerary deposits: burial caves (García-González et al. 2018; Jones et al. 2019; Sarasketa-Gartzia et al. 2018; Villalba-Mouco et al. 2018), pit graves (Fernández-Crespo et al. 2018; Grandal-d'Anglade et al. 2019; Jones et al. 2019) and megalithic monuments (Díaz-Zorita Bonilla et al. 2019; García-González et al. 2018; Jones et al. 2019; Sarasketa-Gartzia et al. 2018).

\section{Historic foodways: transition, culture and religion}

Eleven papers in the volume explore economy and lifeways from the late Roman to the modern era. Entering the historic periods, we often have written documents as a key source of evidence for the economy and consumption patterns, but these generally tend to provide information restricted to the social elites. Where documents such as expenses books are available to offer further in-depth information, they rarely represent the everyday diet (Sarkic et al. 2018). In combination with historical documents, isotopic and osteoarchaeological approaches applied to human remains provide rich information of the lived experience of an individual or group that can unlock information on the 'anonymous' lower strata of society. It is pleasing to see that the papers within this issue do much to tie the isotopic evidence for diet into the sociopolitical and cultural framework provided by historical sources. Dietary evidence is explored along similar themes to that of prehistoryage, sex, social status and faith identities. This can be expanded, however, where we are fortunate to have additional records. For example, López-Costas and Müldner (2018) detected a difference in $\delta^{15} \mathrm{~N}$ values between two parish cemeteries in Pontevedra, Galicia, that could be linked to the marine occupation of parishioners of Santa María. Diachronic patterning in diet is also investigated in the context of political and socioeconomic dynamics in a single place through time (Alexander et al. 2019; Dury et al. 2018; Inskip et al. 2018; Jordana et al. 2019; López-Costas and Müldner 2018; Sarkic et al. 2018) or at many locations on a regional level (MacKinnon et al. 2019). Several articles (Curto et al. 2018; López-Costas and Müldner 2018; MacKinnon et al. 2019; Sarkic et al. 2018) take us into the beginning of modernity, entering a politically significant time for the Peninsula as a key stage for contact with the New World and the Columbian exchange, leading to the introduction of new crops (i.e. maize).

Status in the historic period played a significant role in the access to foods in terms of thier variety, quantity and quality, however, where individuals of differing status have been investigated (defined by burial type, location or grave goods), clear status-based differences in diet are not always apparent in the isotopic data (Alexander et al. 2019; Curto et al. 2018; García-Collado et al. 2018). Where status has been found to correlate with $\delta^{15} \mathrm{C}$ and $\delta^{15} \mathrm{~N}$ values, it is generally manifest through enrichment in ${ }^{15} \mathrm{~N}$ among high-status individuals as a result of greater access to terrestrial animal protein and occasionally aquatic protein (examples from late medieval Spain include Jiménez-Brobeil et al. 2016; Martínez-Jarreta et al. 2018). Dietary differentiation following this pattern was reported in this issue for the Early Medieval population buried at Sant Pere de Terrassa in north-east Spain, where Visigothic individuals show enrichment in both ${ }^{13} \mathrm{C}$ and ${ }^{15} \mathrm{~N}$ in comparison to later Carolingian burials, perhaps signalling a decline in social status for this community during the later period (Jordana et al. 2019). However, in rural sites in Asturias, high-status individuals buried inside churches did not always show elevated $\delta^{15} \mathrm{~N}$ values, instead, they are hypothesised to have consumed more $\mathrm{C}_{4}$ resources (MacKinnon et al. 2019). This is an intriguing finding, for although low sample sizes should be taken into account, this is contrary to what has been proposed both in written sources and isotopic studies in other areas of medieval Spain (Alexander et al. 2015), where $C_{4}$ diets have been associated with low-status diets (see below for a further discussion of $\mathrm{C}_{4}$ plants in the Iberian Peninsula). This really highlights the need for regional studies imbedded into the local context.

Clear sex differences in diet were only identified in a few papers (Alaica et al. 2018; Toso et al. 2019), indicating that either differences in diet were not universal during the historic periods despite the differing roles of men and women in medieval society (Ward 2016), or, that bulk stable isotope analysis is not sensitive enough to reveal subtle differences in diet that may have existed. Sample sizes are often perhaps too small to adequately explore the issue. Nevertheless, Alaica et al. (2018) found that among a population of Late RomanEarly Byzantine individuals from Ibiza, women tended to consume more $\mathrm{C}_{4}$ crops. Toso et al. (2019) also report sex differences in diet among the high-status (but not low status) individuals of São Jorge Castle in Lisbon, revealing that men consumed more higher trophic level protein than females and non-adults, which was hypothesised to reflect the division of male and female roles within the elite Islamic household.

Dietary patterning between age groups is not always explored, in part due to the need for a large sample population with sufficient resolution in age categories; however, there are a few instances where significant differences were revealed. Curto et al. (2018) report higher animal protein intake among young vs. old adults in their population from Tomar. A slight dietary variation between adult age groups was found to be statistically significant among a community of post-medieval nuns (Sarkic et al. 2018). At the Early Medieval site of Boadilla, juveniles exhibit lower $\delta^{15} \mathrm{~N}$ values than the adults at the same site, interpreted as a lower intake in animal protein compared to adults (García-Collado et al. 2018). Four papers 
discussed weaning linked with bulk nitrogen stable isotope values for non-adults in their populations. Despite the generally low sample sizes, weaning appears to have been completed by aged three in Early Medieval (García-Collado et al. 2018), Visigothic (Jordana et al. 2019) and Islamic (Inskip et al. 2018; Toso et al. 2019) contexts. This fits well with elsewhere in Medieval Europe in terms of historical documents (Fildes 1986) and isotopic studies (e.g. see Britton et al. 2018 for a review of UK populations).

Faith, identified through burial rite, is a component of several contributions, where either Islamic or Christian populations are investigated (Table 1). The excavation and analysis of medieval Jewish burial grounds is subject to ongoing controversy and therefore Jewish remains, where they can be identified, tend to be avoided when carrying out destructive analysis (see Colomer 2014 for discussion). So far, it is clear that there is no dietary fingerprint for a particular faith. In this volume, Alexander et al. (2019) explore diet between transitions in religious political rule at one city through time and found that diet in Islamic Valencia was revealed to be highly variable in comparison to the earlier Visigothic and later Christian periods. They link this variability to changes in the economy and culture between each period under differing religious political rule (Alexander et al. 2019). In contrast, when comparing their own and previously published data from pre-Islamic and Islamic sites in Ibiza and Minorca, Dury et al. (2018) see no dietary impact as a result of the Islamic conquest, at least in the isotopic evidence. Inskip et al. (2018) undertake a comprehensive comparison of Christian and Islamic populations published so far for medieval Spain and conclude that where differences do exist, they tend to be on a local level and related to status or political rule. We would like to see future dietary studies considering faith in the sociocultural context of particular locality, perhaps targeting the interplay of faith and food between contemporaneous populations of Christians and Muslims (e.g. Alexander et al. 2015) or continuing to investigate economies through time under differing religious political rule.

Despite the evidence from historic documents and the influence of Christian fasting, fish consumption is unclear in the isotopic data from many areas of the Iberian Peninsula. Unfortunately, fish remains do not feature frequently in zooarchaeological assemblages from the Peninsula due to excavation techniques employed by necessity in commercial archaeology, although this is changing. Curto et al. (2018) interpret sulphur data alongside carbon and nitrogen to argue for the consumption of aquatic (freshwater) protein in Tomar as a result of religious dietary restrictions associated with the presence of the Christian military orders. Post-medieval nuns at the convent of Santa Catalina de Siena, however, probably consumed only small amounts of fish despite their Christian monastic status, instead they decreased their terrestrial animal protein intake, following the dietary restrictions of their order
(Sarkic et al. 2018). López-Costas and Müldner (2018) report clear evidence for marine fish consumption by Christian communities on the Atlantic coast, despite the presence of $\mathrm{C}_{4}$ protein in the diets that led to only moderately ${ }^{15} \mathrm{~N}$-enriched nitrogen isotope values, a phenomenon also reported for other sites in coastal north-west Iberia (López-Costas and Müldner 2016). Marine foods, however, appear to be intriguingly absent from the diet of the Islamic population of Lisbon, despite their location on the Atlantic coast (Toso et al. 2019). The lack of marine fish consumption on the Mediterranean coast and the islands (Alaica et al. 2018; Alexander et al. 2019; Dury et al. 2018) is surprising and is probably due to the limitation of bulk isotopic analysis in the Mediterranean, an area of comparatively low productivity compared to the Atlantic, where nitrogen values for marine resources tend to be lower due to the shorter length of the food chain. This is an issue particularly in areas where $\mathrm{C}_{4}$ input could confound the isotopic signal due to equifinality where isotopic endmembers for $\mathrm{C}_{4}$-fed animals and marine resources are not sufficiently distinguished (Alexander et al. 2019; Dury et al. 2018).

\section{Introduction and use of $\mathrm{C}_{4}$ plants in human and animal diet}

The climate in Iberian Peninsula is suitable for several species of $\mathrm{C}_{4}$ plants. The most important to human and animal diets are millets, sorghum, sugarcane and maize. Their introduction and consumption are a major issue for palaeodiet in the Iberian Peninsula and as a result, $\mathrm{C}_{4}$ crops consumption is considered within the majority of the articles of the special issue. There is an intense debate surrounding the timing of the introductions of millets during the Middle or Late Bronze Age (see discussion in López-Costas et al. 2015b). No evidence of $\mathrm{C}_{4}$ plant consumption has been detected during Neolithic to Middle Bronze Age in northern, north-eastern and south-eastern sites (Díaz-Zorita Bonilla et al. 2019; Fernández-Crespo et al. 2018; Jones et al. 2019; Sarasketa-Gartzia et al. 2018; VillalbaMouco et al. 2018). In these cases, if $\mathrm{C}_{4}$ plants were a component in human diet, then they were not being consumed in sufficient quantities to register in bone collagen. From the Mesolithic to the Late Neolithic-Chalcolithic, human and animal food is almost exclusively connected to $\mathrm{C}_{3}$-based terrestrial resources and marine resources on the coast (Cubas et al. 2018). Nevertheless, elevated $\delta^{13} \mathrm{C}$ signatures in a possibly domestic fox from Can Roqueta (Barcelona) (Grandald'Anglade et al. 2019) were interpreted as feeding with millet, again opening the debate about the use of millet in Prehistory. In addition, we think that the slight enrichment in ${ }^{13} \mathrm{C}$ in the Bronze Age Argar societies observed by Díaz-Zorita Bonilla et al. (2019) could also be connected to small amount of millets in the diet. Isotopic signatures altogether only reflect staple or major food intake. It is possible that the spread of millets 
may not have had a connection with their introduction to the farming economy: some populations may have known of millets but chose not to consume them in any significant amount. A scenario of discontinuous spread of new crops is also possible, as was noted in northern Italy (Tafuri et al. 2018).

Millets were used regularly in the Iberian Peninsula from the Iron Age onwards (Alonso 1999) and are considered to be the only $\mathrm{C}_{4}$ plant available until the eighth century AD (PeñaChocarro et al. 2019). Archaeobotanical evidence indicates that although naked wheat was probably predominant, broomcorn and foxtail millet were consumed in the Roman period and their presence increased in later medieval Christian and Islamic sites, with no clear differences between them (PeñaChocarro et al. 2019). The amount of millet in the diet has been positively correlated with low-status when analysing Roman necropolises (see discussion in Alaica et al. 2018). The paper from this issue reports that during Late Antiquity/ Early Medieval period (AD fourth/fifth to tenth centuries), small but regular amounts of $\mathrm{C}_{4}$ plants were eaten by some animals (fowl and one dog) and humans from Boadilla in Central Spain (García-Collado et al. 2018), as well as humans in Terrassa, Northeast Iberia (Jordana et al. 2019) and from San Bartolomeu in Ibiza (Dury et al. 2018). In the latter study, the combined use of $\delta^{13} \mathrm{C}$ from collagen and bioapatite revealed a possible higher dependence of millet during childhood or different place of origin where $\mathrm{C}_{4}$ crops dominated (Dury et al. 2018).

$\mathrm{C}_{4}$ crops such as millets and white and red sorghum are historically documented in Islamic and Christian Valencia and corroborated by isotopic analyses of both humans and animals (Alexander et al. 2019). However, while $\mathrm{C}_{4}$ plants seem staple and widely used under Islamic rule, after the Christian conquest their importance was diminished and they were possibly more associated with lower social orders and rural populations (Alexander et al. 2019). Note that Dury et al. (2018) have pointed Valencia as an area of possible provenance for their ${ }^{13} \mathrm{C}$ enriched individual from Ibiza. In Christian medieval sites, the consumption of millets seems to also differ regarding location and, occasionally, social status. While millets were not a staple for high-status Islamic individuals buried at São Jorge Castle in Lisbon or the local analysed fauna (Toso et al. 2019), contemporary middle-low class from Christian Pontevedra town, for example, consumed them in a noticeable quantity (López-Costas and Müldner 2018).

After the ninth century, sugar cane was introduced though the Islamic world for household consumption (Perez Vidal 1973; Sato 2015) and become an export product several centuries later (for more info see Inskip et al. 2018). Due to the low protein intake of sugarcane molasses, its detection in paleodietary reconstruction is only possible when combining the isotopic study of carbon in both collagen and bioapatite (Ambrose et al. 1997). Carbon and oxygen isotopes in bioapatite have been rarely applied to Iberian sites (e.g.
Dury et al. 2018; Inskip et al. 2018; Saragoça et al. 2016). In this issue, the Islamic population from Ecija (Sevilla) was found to possess $\delta^{13} \mathrm{C}$ values of enamel apatite that are compatible with consumption of sugarcane, at least in childhood (Inskip et al. 2018).

Maize arrived in the Iberian Peninsula in the sixteenth century and was mainly used for feeding livestock. Maize grew extremely well in poor north-western Iberian (Galicia, Asturias, northern Portugal) soils and became a popular option for medium-low-status families, where it diplaced millets. Galicia was characterised by an intense use of $\mathrm{C}_{4}$ plants (i.e. millets) in Roman period (López-Costas and Müldner 2016), that was maintained until the medieval period, as observed at Pontevedra (López-Costas and Müldner 2018). The environmental crises in the sixteenth century and famines as a result of the harsh conditions of the Little Ice Age, culminated in a wider dependence on maize in Galicia (López-Costas and Müldner 2018). This displacement of millets by maize has been also discussed for multiple Asturian sites (MacKinnon et al. 2019). Here, $C_{4}$ plant consumption has been observed in skeletons from in rural monastic communities where $\mathrm{C}_{4}$ plants may have been a part of monks ascetic lives (MacKinnon et al. 2019). The use of $C_{4}$ plants as animal fodder in north-western Iberia has a strong connection with ethnobotanic practices in the area today (Moreno-Larrazabal et al. 2015). The consumption of maize was also hypothesised for the post-medieval community of nuns in Belmonte (Cuenca, Central Spain) where a possible increase in $\mathrm{C}_{4}$ plant consumption, (maize and/or sugar) occurred during the 19th and 20th centuries AD (Sarkic et al. 2018). The authors suggest a possible relationship between pathology and high $\delta^{13} \mathrm{C}$ values that could relate to special diet rich in maize/sugar.

As motioned above, however, distinguishing between the consumption of $\mathrm{C}_{4}$ plants either directly or indirectly (though consuming $\mathrm{C}_{4}$-fed animal protein) and the consumption of aquatic recourses is challenging using $\delta^{13} \mathrm{C}$ and $\delta^{15} \mathrm{~N}$, even in combination with $\delta^{34} \mathrm{~S}$, as discussed by Curto et al. (2018).

\section{Paleodiet and paleopathology}

The connection between palaeodietary reconstruction by geochemical analyses and the presence of pathological features is a challenge that has not been adequately addressed as yet (see for example López-Costas et al. 2015a; Richards and Montgomery 2012). Katzenberg and Lovell (1999) demonstrated early on that isotopic values of bone collagen can be affected by physiological stress in pathological bone (i.e. nitrogen values are affected by the increase of muscle catabolism). Similar results were found recently by Ana Curto et al. (2019) in a subsample from the Tomar necropolis, whose "healthier" individuals were studied in this issue (Curto et al. 2018). In all cases, despite the apparent connection between 
isotopes and stress, a change in dietary preferences due to illness cannot be dismissed. The latter was hypothesised by Sarkic et al. (2018), who compare isotopic values for carbon and nitrogen with the presence of chronic systemic pathologies such as osteoporosis, periostitis, and brucellosis. They found a significant increase in $\delta^{13} \mathrm{C}$ values that they connected to a possible preference for maize/sugar-rich diets in nuns with these conditions.

The relationship between isotopic methods and oral pathology is an obvious comparison since both provide information on diet; however, few direct links have been found between both (see a summary in Richards and Montgomery 2012). Jordana et al. (2019) produce an interesting comparison between the intake of millets and dental wear-millet tends to have a high silica content and is therefore more abrasive. A very low frequency of caries in comparison with contemporary sites was reported in the high status population from Lisbon, which suggests a reliance on animal products in the diet (Toso et al. 2019). The authors also reveal a low presence of stress indicators including dental enamel hypoplasia and cribra orbitalia, a finding that could be connected to both better health conditions or more fragile individuals who died before developing chronic markers (Toso et al. 2019).

The relationship between pathological features and isotopic signatures has been also addressed in animals. Spine pathologies in Bronze Age dogs from north-east Spain were linked to a higher input of plant food and a scarcity of animal protein in the diet, inferred from their isotopic signature (Grandald'Anglade et al. 2019). This poor nutrition status may have enhanced the development of a degenerative disease called spondylosis deformans that has been related by these authors the use of the dog as work animal (Grandal-d'Anglade et al. 2019), aspects an interpretations also discussed by Janssens and Lawler (2019).

Although it is not a pathological sign, stature can be also connected to stress and nutrition during grown. Estimates of height calculated from bone measurements were compared with collagen isotopic signatures for the Late Medieval cemetery at Pontevedra (López-Costas and Müldner 2018). Despite the lack of correlation in this case, this approach opens new lines for connecting dietary reconstruction with skeletal features.

\section{Migrations}

Human lifestyle depends very much on where an individual lives and many papers in this special issue therefore consider mobility in their interpretations of diet. Paleomobility has been directly approached through the use of ${ }^{87} \mathrm{Sr} /{ }^{86} \mathrm{Sr}$ (Sarasketa-Gartzia et al. 2018), $\delta^{18} \mathrm{O}_{\text {carb }}$ (Dury et al. 2018) and $\delta^{34} \mathrm{~S}$ (Curto et al. 2018; Jones et al. 2019) —although the latter is also considered as a marker of marine and freshwater input (Curto et al. 2018; Díaz-Zorita Bonilla et al. 2019). Different geographic origins have also been hypothesised indirectly from variations in isotopic fingerprints for diet, i.e. dietary outliers (Alexander et al. 2019; Dury et al. 2018; Fernández-Crespo et al. 2018; Toso et al. 2019), although individual choice or restriction on food cannot be ruled out. In other cases, a different diet has been linked to cultural shifts rather than population displacement (Jordana et al. 2019).

Movement of people during Chalcolithic in the northcentral Spain has been suggested by several authors (Jones et al. 2019; Sarasketa-Gartzia et al. 2018). At these sites, locals and non-locals were buried together and shared a similar diet (Sarasketa-Gartzia et al. 2018), although some of them also showed different dietary intakes (Jones et al. 2019). However, age- and sex-related isotopic (Fernández-Crespo et al. 2018) and dental microwear (García-González et al. 2018) differences are also identified suggesting a complicated panorama where division of labour and socioeconomic status have to be considered (Fernández-Crespo et al. 2018).

Smaller scale intra-regional movements were considered for Chalcolithic sites in north-central Iberia as connections between the coast and inland (Jones et al. 2019), and as rural-urban movements in medieval Valencia (Alexander et al. 2019). For an early medieval site in Ibiza, differences in $\mathrm{C}_{4}$ intake between child- and adulthood have been interpreted as movements from mainland Iberia to the island (Dury et al. 2018). Intra-regional mobility for animals has been proposed as an explanation for carbon and nitrogen isotopic variation in Ecija herbivores under Islamic rule (Inskip et al. 2018), where different husbandry practices may have been used in the arid and saline environment of the near Ecija plateau (Altiplano de Écija) (Inskip et al. 2018). A similar argument was made for the diversity in animal isotopic values for Valencia (Alexander et al. 2019), which would have been drawing on a wide catchment of resources to feed the city.

Religious practice was also a driver for people to move in the past, pilgrimage in particular was a major aspect of life in the middle ages for many faiths. Exciting questions about large migrations related to the Camino de Santiago pilgrimage have been proposed. Pilgrimage was mooted as a suitable explanation for isotopic outliers in skeletal assemblages in places devoted to host pilgrims, such as the Hospital and Church of San Juan Bautista (Asturias) (MacKinnon et al. 2019). However, as the authors pointed out, differentiating a pilgrim from a non-local individual is not possible based using skeletal evidence alone.

\section{Animals, the importance of local baseline}

Husbandry practices and the diets of wild/domestic animals have been referred to in almost all manuscripts. Interesting 
debates about human-animal relationships have been proposed, most notably in the case of the double burials for dogs/foxes and humans found in Bronze Age north-eastern Iberia (Grandal-d'Anglade et al. 2019). There are good reasons for including animal samples in isotopic studies. In contrast to other techniques such as dental microwear, it is considered mandatory to incorporate animals when reconstructing diet using stable isotope analyses in order to trace the local baseline. Animals and, ideally, plant remains are used as markers of potential dietary sources for humans. To provide a baseline that is as accurate as possible, samples should come from the same cemetery/settlement as the human sample (or as geographically close as possible) and date to the same chronological period and cover most of potential dietary sources. Studies tend to lack samples of marine and freshwater fish mainly because of their scarcity in the archaeological record due to recovery techniques and the fact that the often-fragmentary state of the bones means that they do not always survive.

Establishing a local baseline in an area with a large range of environments, such as the Iberian Peninsula, is crucial. To illustrate this, we selected one of the herbivore groups often included in studies, the caprine (or ovicaprids, sheep/goat), and explore the variability of their carbon and nitrogen isotopic values across all the publications in the special issue. Figure 2 shows that the intra- and inter-site variation is wide and has no a clear pattern regarding chronological period or geographic area. The total range in $\delta^{13} \mathrm{C}$ is $9.1 \%$ (from -22.2 to $-13.1 \%$; average $-20.0 \pm 1.1 \%$, 1 s.d.) and $\delta^{15} \mathrm{~N}$ is $9.9 \%$ (from 12.3 to $2.3 \%$; average $6.5 \pm 2.0 \% 01$ s.d.). Values for both the endpoints in $\delta^{13} \mathrm{C}$ are from medieval north-western sites (Asturias and Galicia), where $\mathrm{C}_{4}$ plants were used as animal fodder. When those areas are not considered, carbon isotopic values are constricted into a mainly $\mathrm{C}_{3}$ plant environment (from -21.6 to $-18.6 \%$; range of $3 \%$ ), but with no significant changes in the average $(-20.1 \pm 0.7 \%$ ). Nitrogen shows a continuous variation and has been connected to arid/ wet environment, salinity and different husbandry practices (e.g. enclosure, transhumance) that are difficult to assess a priori.

The (small) sample size effect is shown in Fig. 3. There is a trend of decreasing standard deviation as the number of individuals increases. The nitrogen values show much higher variability than carbon, especially when north-western sites are excluded for the latter. This limited comparison of data from just two genera (sheep/goat; Ovis/Capra) from the papers in this special issue indicates that a local, contemporaneous animal baseline is needed to characterise human diet effectively and it should be relatively extensive in terms of sample numbers. Sample size is critical for achieving a good perspective of local variability. We recommend an animal/human sample ratio of between 0.3 and 0.5 , and even greater than 1.0 if the sample is small or $\mathrm{C}_{4}$ plants were used for animal fodder (see ratios in Table 1). In addition, we agree with Villalba-Mouco et al. (2018) in advising caution when interpreting diet in isotopic studies comparing human values from different regions and/or chronologies.

\section{A gender perspective on authorship}

We would like to take the opportunity to use the authorship of the papers included in this special issue to reflect on academic society more generally, with the aim of hopefully contributing to a more positive future. During the last decade, a significant

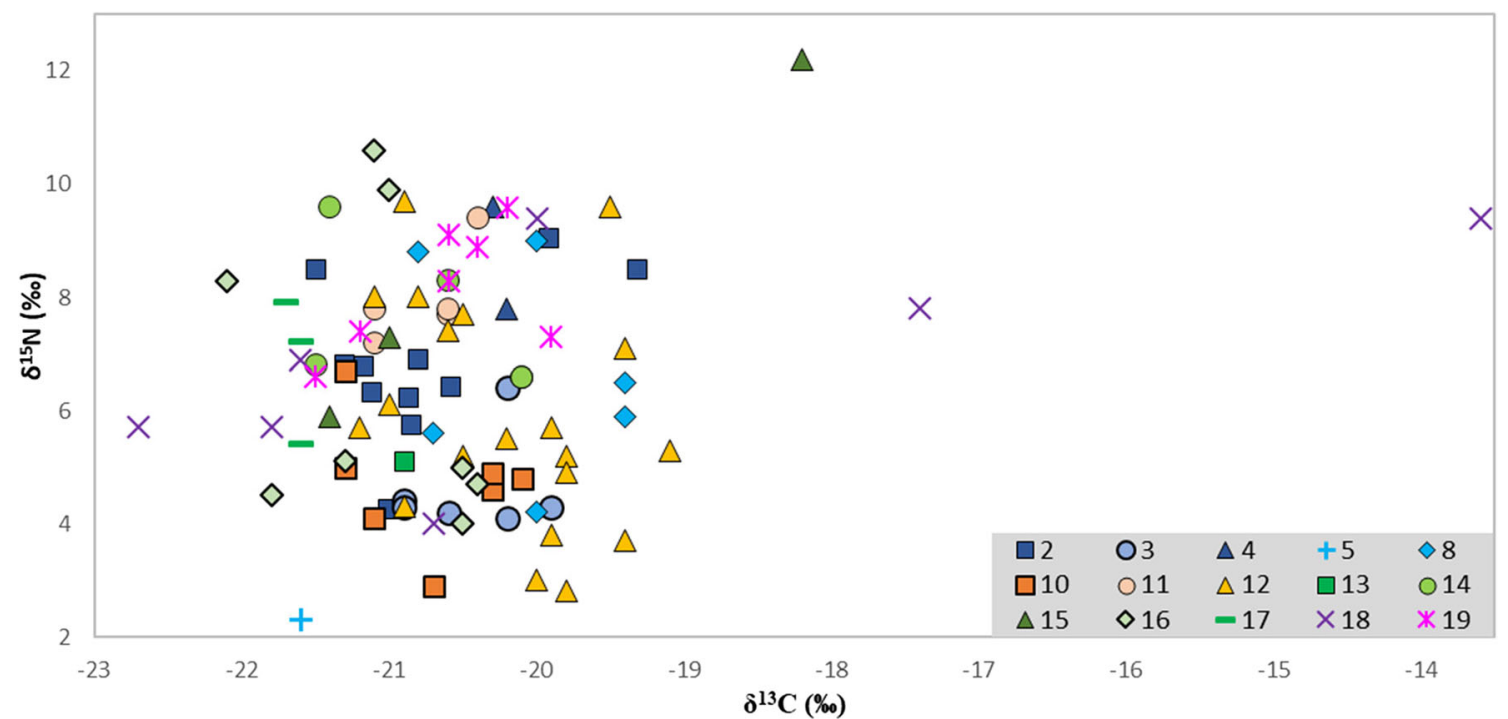

Fig. 2 Scatterplot of bone collagen $\delta^{13} \mathrm{C}$ and $\delta^{15} \mathrm{~N}$ for caprine samples (recorded as ovicaprid, ovis, capra, sheep/goat, C. hircus, O. aries and ovicapridae) of the articles of "Iberian Paleodiet". Young individuals and samples obtained from literature were excluded. Articles codes are those

found in Table 1. Prehistoric samples are in blue, Late Antique and Early Medieval in orange, Late Medieval and post-Medieval are in green and purple respectively 


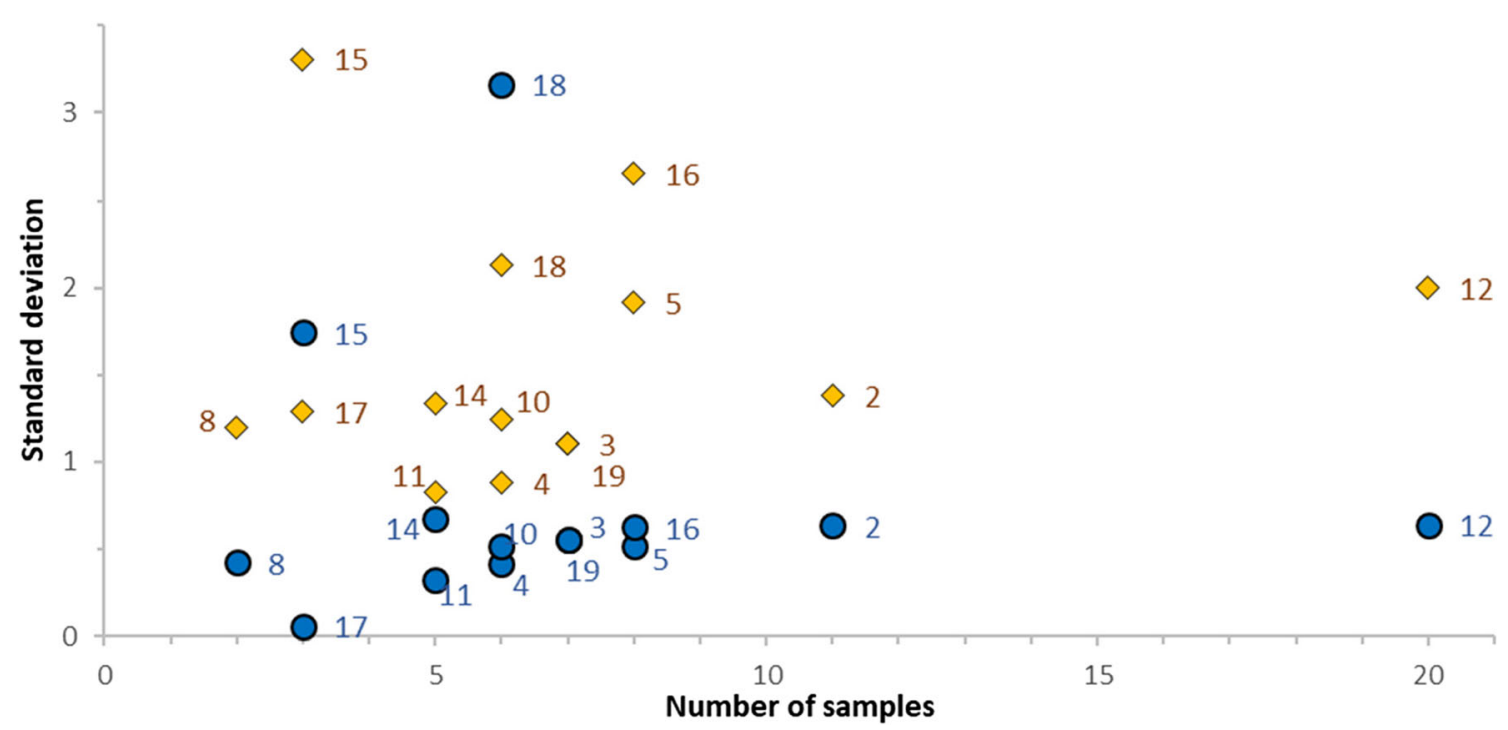

Fig. 3 Scatterplot showing the relationship between the number of Caprinae samples and the standard deviation of bone collagen $\delta^{13} \mathrm{C}(\mathrm{blue}$ circles) and $\delta^{15} \mathrm{~N}$ (orange diamonds) in each article. Young individuals and samples obtained from literature were excluded. Articles codes are those found in Table 1

gender bias has been reported for Archaeology and Physical Anthropology (Bardolph 2014; Turner et al. 2018). Despite being more active in obtaining a $\mathrm{PhD}$ or completing a dissertation, women used to author a much lower percentage of papers in archaeological journals than men (Bardolph 2014). Publication, especially in peer-review journals, is one of the challenges that archaeological and anthropological science community must face (Tushingham et al. 2017). It is notable, however, that the wide majority of the papers included in this special issue have a female researcher as first and/or corresponding author, a total of 17/19 contributions (89\%). In addition, $70 \%$ of reviewers were female (31/44), although only $57 \%(28 / 49)$ of the reviewers that were suggested by authors were female.

The high percentage of female contributors probably corresponds to the elevated number of females working and publishing in bioarchaeology in the present and fits with current trend in this subject (Turner et al. 2018). The study of paleodietary reconstruction in osteoarchaeological human remains is presently mainly conducted by female researchers; however, any gender bias in publication is a concern we should all be aware of. It is still necessary to encourage (young) female researchers to submit their work to peerreview international journals, especially those from countries with a weaker tradition of publishing in the English language. Finally, we also consider it important to bare gender equality in mind when suggesting potential reviewers for our papers.

\section{Future panorama}

Environmental variables, such as elevation, temperature and precipitation, have been suggested as an explanation for different patterns in dental microwear between Atlantic and Mediterranean coast (García-González et al. 2018). There is a general need for wider sampling of animal remains in terms of numbers and range of species to better characterise the local environmental variation. Similarly, sampling needs to extend to plant remains (currently a rare resource) in the future. The growing number of palaeodietary studies increasingly allows for investigating cultural, religious and economic factors on a regional scale. Local trends in diet are emerging that are related to the environment but also to unique sociocultural histories, which is which is important to bear in mind before making inter-regional comparisons in isotopic data that may not be appropriate. There is also a need to imbed the isotopic data into existing zooarchaeological and archaeobotanical data, where available, to provide an integrated and holistic picture of diet. The same issue can be extended to osteological and paleopathological data from the studied populations, which are still not included when discussing dietary reconstruction, even if they are mentioned when providing the introductory context for a population under study.

Hopefully, we will soon witness further research that plugs the chronological gap, with a focus on Iron Age, Roman and early medieval populations which will enable us to undertake a wider diachronic comparisons between key transition periods in human societies in the Peninsula.

Isotopic studies are making increasing use of isotopes and substrates beyond that of carbon and nitrogen applied to bone collagen. In this special issue, we have witnessed the application of sulphur (Curto et al. 2018; Díaz-Zorita Bonilla et al. 2019; Jones et al. 2019) and bioapatite (Dury et al. 2018; Inskip et al. 2018) to explore diet. As new technology allows for sequential measurement of C, $\mathrm{N}$ and $\mathrm{S}$ in the same, (small) aliquot of collagen (Sayle 
et al. 2019), we are going to see a lot more sulphur data emerging in the future. When targeting the $\mathrm{C}_{4} /$ marine protein issue, analysing bioapatite and sulphur offers some possibilities, in particular when combined with mixing models such as FRUITS analysis (e.g. Cubas et al. 2018; Fernandes et al. 2015). Analysis of single amino acids in bone collagen also offer a promising area of inquiry (Corr et al. 2005).

Finally, the exponential increase of destructive analysis of Portuguese and Spanish skeletal collection initiates necessary ethical considerations. Follow an ethical code, try and sample exclusively when the osteological study has been completed, minimise the destructive analysis, combine them with nondestructive techniques where possible and keep a record of what has been sampled, this necessary to preserve Iberian heritage for future generations.

Acknowledgements We would like to thank all the authors and research groups that have participated in this issue. We have good-quality contributions and we are grateful for the smooth editorial process we experienced with the authors. We personally encourage the contributors to continue working on Iberian Peninsula skeletal collections and helping to answer past and new questions. A huge thanks also goes to the 44 anonymous reviewers that helped to improve the quality of the manuscripts.

During this special issue, a new baby was born providing us new perspectives for our (research) lives. Along this 2-year process, we both grew dealing with personal issues such as maternity and sick leave and we want to thank the editors of the journal and authors for their understanding. Thanks to László Bartosiewicz for reminding us that the Iberian Peninsula is a subcontinent, as true an statement that we feel the need to borrow it for our introduction.

Funding information This special issue was possible for OLC due to the research time obtained by the projects Galician Paleodiet (ED481D 2017/014), Consiliencia network (ED 431D2017/08), axudas a grupos con potencial de crecemento (ED431B 2018/20) all funded by Xunta de Galicia, and axudas para o financiamento singular de grupos de investigación (2018-PU029) funded by Universidade de Santiago de Compostela.

\section{References}

Alaica AK, Schalburg-Clayton J, Dalton A, Kranioti E, Graziani Echávarri G, Pickard C (2018) Variability along the frontier: stable carbon and nitrogen isotope ratio analysis of human remains from the Late Roman-Early Byzantine cemetery site of Joan Planells, Ibiza, Spain. Archaeol Anthropol Sci

Alexander MM, Gerrard CM, Gutiérrez A, Millard AR (2015) Diet, society, and economy in late medieval Spain: stable isotope evidence from Muslims and Christians from Gandía, Valencia. Am J Phys Anthropol 156(2):263-273

Alexander MM, Gutiérrez A, Millard AR, Richards MP, Gerrard CM (2019) Economic and socio-cultural consequences of changing political rule on human and faunal diets in medieval Valencia (c. fifthfifteenth century AD) as evidenced by stable isotopes. Archaeol Anthropol Sci

Alonso N (1999) De la llavor a la farina. Els processos agrícoles protohistórics a la Catalunya occidental. Monographies d'Archéologie Méditerranéennes, Lattes 4
Ambrose SH, Butler BM, Hanson DB, Hunter-Anderson RL, Krueger HW (1997) Stable isotopic analysis of human diet in the Marianas Archipelago, Western Pacific. Am J Phys Anthropol 104(3):343361

Bardolph DN (2014) A critical evaluation of recent gendered publishing trends in American archaeology. Am Antiq 79(3):522-540

Britton K, McManus-Fry E, Cameron A, Duffy P, Masson-MacLean E, Czére O, Smith N, Stones J, Winfield A, Müldner G (2018) Isotopes and new norms: investigating the emergence of early modern U.K. breastfeeding practices at St. Nicholas Kirk, Aberdeen. Int J Osteoarchaeol 28(5):510-522

Colomer L (2014) The politics of human remains in managing archaeological medieval Jewish burial grounds in Europe. Nordisk Kulturpolitisk Tidskrift 17(02):168-186

Corr LT, Sealy JC, Horton MC, Evershed RP (2005) A novel marine dietary indicator utilising compound-specific bone collagen amino acid delta C-13 values of ancient humans. J Archaeol Sci 32(3):321330

Cubas M, Peyroteo-Stjerna R, Fontanals-Coll M, Llorente-Rodríguez L, Lucquin A, Craig OE, Colonese AC (2018) Long-term dietary change in Atlantic and Mediterranean Iberia with the introduction of agriculture: a stable isotope perspective. Archaeol Anthropol Sci

Curto A, Maurer A-F, Barrocas-Dias C, Mahoney P, Fernandes T, Fahy GE (2018) Did military orders influence the general population diet? Stable isotope analysis from Medieval Tomar, Portugal. Archaeol Anthropol Sci

Curto A, Mahoney P, Maurer A-F, Barrocas-Dias C, Fernandes T, Fahy GE (2019) Diet and disease in Tomar, Portugal: comparing stable carbon and nitrogen isotope ratios between skeletons with and without signs of infectious disease. J Archaeol Sci 105:59-69

Decker M (2009) Plants and progress: rethinking the Islamic agricultural revolution. J World Hist 20(2):187-206

Díaz-Zorita Bonilla M, Aranda Jiménez G, Bocherens H, Escudero Carrillo J, Sánchez Romero M, Lozano Medina Á, Alarcón García E, Milesi García L (2019) Multi-isotopic diet analysis of southeastern Iberian megalithic populations: the cemeteries of El Barranquete and Panoría. Archaeol Anthropol Sci

Dury G, Lythe A, Marquez-Grant N, Garcia-Rubio A, Graziani G, Mari J, Ziriax M, Schulting R (2018) The Islamic cemetery at 33 Bartomeu Vicent Ramon, Ibiza: investigating diet and mobility through light stable isotopes in bone collagen and tooth enamel. Archaeol Anthropol Sci

Fernandes R, Grootes P, Nadeau MJ, Nehlich O (2015) Quantitative diet reconstruction of a Neolithic population using a Bayesian mixing model (FRUITS): the case study of Ostorf (Germany). Am J Phys Anthropol 158(2):325-340

Fernández-Crespo T, Ordoño J, Barandiarán I, Andrés MT, Schulting RJ (2018) The Bell Beaker multiple burial pit of La Atalayuela (La Rioja, Spain): stable isotope insights into diet, identity and mortuary practices in chalcolithic Iberia. Archaeol Anthropol Sci

Fildes V (1986) Breasts, bottles and babies-a history of infant feeding. Edinburgh University Press

García-Collado MI, Ricci P, Catalán Ramos R, Altieri S, Lubritto C, Quirós Castillo JA (2018) Palaeodietary reconstruction as an alternative approach to poorly preserved early medieval human bone assemblages: the case of Boadilla (Toledo, Spain). Archaeol Anthropol Sci

García-González R, Sánchez-Puente Z, Arsuaga JL, Carretero JM (2018) Dietary inferences from dental microwear patterns in chalcolithic populations from the Iberian Peninsula: the case of El Portalón de Cueva Mayor (Sierra de Atapuerca, Burgos, Spain) and El Alto de la Huesera (Álava, Spain). Archaeol Anthropol Sci

Grandal-d'Anglade A, Albizuri S, Nieto A, Majó T, Agustí B, Alonso N, Antolín F, López JB, Moya A, Rodríguez A et al (2019) Dogs and foxes in Early-Middle Bronze Age funerary structures in the northeast of the Iberian Peninsula: human control of canid diet at the sites 
of Can Roqueta (Barcelona) and Minferri (Lleida). Archaeol Anthropol Sci

Inskip S, Carroll G, Waters-Rist A, López-Costas O (2018) Diet and food strategies in a southern al-Andalusian urban environment during Caliphal period, Écija, Sevilla. Archaeol Anthropol Sci

Janssens LAA, Lawler DF (2019) Were foxes really domesticated, and were dogs really beasts of burden, during the Bronze Age in Northeast Spain? Archaeol Anthropol Sci

Jiménez-Brobeil S, Laffranchi Z, Maroto R, Sánchez FL, Huertas AD (2016) How royals feasted in the court of Pedro I of castile: a contribution of stable isotope study to medieval history. J Archaeol Sci Rep 10:424-430

Jones JR, Maeso CV, Ballestero EC, Martín LV, Arceo MED, MarínArroyo AB (2019) Investigating prehistoric diet and lifeways of early farmers in central northern Spain (3000-1500 CAL BC) using stable isotope techniques. Archaeol Anthropol Sci

Jordana X, Malgosa A, Casté B, Tornero C (2019) Lost in transition: the dietary shifts from Late Antiquity to the Early Middle Ages in the North Eastern Iberian Peninsula. Archaeol Anthropol Sci

Katzenberg MA, Lovell NC (1999) Stable isotope variation in pathological bone. Int J Osteoarchaeol 9(5):316-324

López-Costas O, Müldner G (2016) Fringes of the empire: diet and cultural change at the Roman to post-Roman transition in NW Iberia. Am J Phys Anthropol 161(1):141-154

López-Costas O, Müldner G (2018) Boom and bust at a medieval fishing port: dietary preferences of fishers and artisan families from Pontevedra (Galicia, NW Spain) during the Late Medieval and Early Modern Period. Archaeol Anthropol Sci

López-Costas O, Müldner G, Grandal DÁnglade A (eds) (2015a) Paleodiet meets paleopathology: using skeletal biochemistry to link ancient health, food and mobility. Rede Consiliencia and JAS Arqueología SLU, Santiago de Compostela

López-Costas O, Müldner G, Martínez Cortizas A (2015b) Diet and lifestyle in Bronze Age Northwest Spain: the collective burial of Cova do Santo. J Archaeol Sci 55(0):209-218

MacKinnon AT, Passalacqua NV, Bartelink EJ (2019) Exploring diet and status in the Medieval and Modern periods of Asturias, Spain, using stable isotopes from bone collagen. Archaeol Anthropol Sci

Martínez-Jarreta B, Sosa C, Laliena C, Budowle B, Hedges REM (2018) Stable isotope and radiocarbon dating of the remains of the Medieval Royal House of Aragon (Spain) shed light on their diets, life histories and identities. Archaeometry 60(2):366-382

Moreno-Larrazabal A, Teira-Brión A, Sopelana-Salcedo I, ArranzOtaegui A, Zapata L (2015) Ethnobotany of millet cultivation in the north of the Iberian Peninsula. Veg Hist Archaeobotany 24(4): 541-554

Peña-Chocarro L, Pérez- Jordà G, Alonso N, Antolín F, Teira-Brión A, Tereso JP, Montes Moya EM, López Reyes D (2019) Roman and medieval crops in the Iberian Peninsula: a first overview of seeds and fruits from archaeological sites. Quat Int 499:49-66

Perez Vidal J (1973) La cultura de la caña de azucar en el Levante Español. In: Consejo Superior de Investigaciones Científicas, Madrid

Pluskowski A, Boas AJ, Gerrard C (2011) The ecology of crusading: investigating the environmental impact of holy war and colonisation at the frontiers of medieval Europe. Mediev Archaeol 55(1):192225

Richards M, Montgomery J (2012) Isotope analysis and paleopathology. A short review and future developments. In: Buikstra JE, Roberts C (eds) The global history of paleopathology: pioneers and prospects. Oxford University Press, Oxford, pp 718-731
Saragoça P, Maurer A-F, Šoberl L, Lopes MC, Alfenim R, Leandro I, Umbelino C, Fernandes T, Valente MJ, Ribeiro S et al (2016) Stable isotope and multi-analytical investigation of Monte da Cegonha: a Late Antiquity population in southern Portugal. J Archaeol Sci Rep 9:728-742

Sarasketa-Gartzia I, Villalba-Mouco V, Le Roux P, Arrizabalaga Á, Salazar-García DC (2018) Anthropic resource exploitation and use of the territory at the onset of social complexity in the NeolithicChalcolithic Western Pyrenees: a multi-isotope approach. Archaeol Anthropol Sci

Sarkic N, López JH, López-Costas O, Grandal-d'Anglade A (2018) Eating in silence: isotopic approaches to nuns' diet at the convent of Santa Catalina de Siena (Belmonte, Spain) from the sixteenth to the twentieth century. Archaeol Anthropol Sci

Sato T (2015) Sugar in the social life of Medieval Islam. Bill, Leiden

Sayle KL, Brodie CR, Cook GT, Hamilton WD (2019) Sequential measurement of $\delta 15 \mathrm{~N}, \delta 13 \mathrm{C}$ and $\delta 34 \mathrm{~S}$ values in archaeological bone collagen at the Scottish Universities Environmental Research Centre (SUERC): a new analytical frontier. Rapid Commun Mass Spectrom

Schurr MR, Hayes RG (2008) Stable carbon-and nitrogen-isotope ratios and electron spin resonance (ESR) g-values of charred bones: changes with heating and a critical evaluation of the utility of $g$ values for reconstructing thermal history and original isotope ratios. J Archaeol Sci 35(7):2017-2031

Tafuri MA, Rottoli M, Cupitò M, Pulcini ML, Tasca G, Carrara N, Bonfanti F, Salzani L, Canci A (2018) Estimating C4 plant consumption in Bronze Age Northeastern Italy through stable carbon and nitrogen isotopes in bone collagen. Int J Osteoarchaeol 28(2): $131-142$

Toso A, Gaspar S, Banha da Silva R, Garcia SJ, Alexander M (2019) High status diet and health in Medieval Lisbon: a combined isotopic and osteological analysis of the Islamic population from São Jorge Castle, Portugal. Archaeol Anthropol Sci

Turner TR, Bernstein RM, Taylor AB, Asangba A, Bekelman T, Cramer JD, Elton S, Harvati K, Williams-Hatala EM, Kauffman L, Middleton E, Richtsmeier J, Szathmáry E, Torres-Rouff C, Thayer Z, Villaseñor A, Vogel E (2018) Participation, representation, and shared experiences of women scholars in biological anthropology. Am J Phys Anthropol 165(S65):126-157

Tushingham S, Fulkerson T, Hill K (2017) The peer review gap: a longitudinal case study of gendered publishing and occupational patterns in a female-rich discipline, Western North America (1974-2016). PLoS One 12(11):e0188403

Twiss K (2012) The archaeology of food and social diversity. J Archaeol Res 20(4):357-395

Villalba-Mouco V, Sarasketa-Gartzia I, Utrilla P, Oms FX, Mazo C, Mendiela S, Cebrià A, Salazar-García DC (2018) Stable isotope ratio analysis of bone collagen as indicator of different dietary habits and environmental conditions in northeastern Iberia during the 4th and 3rd millennium cal B.C. Archaeol Anthropol Sci

Ward J (2016) Women in Medieval Europe 1200-1500: Routledge

Watson AM (1974) The Arab agricultural revolution and its diffusion, 700-1100. J Econ Hist 34(1):8-35

Publisher's note Springer Nature remains neutral with regard to jurisdictional claims in published maps and institutional affiliations. 